\title{
POSSÍVEIS INCONSTITUCIONALIDADES NA REGULAMENTAÇÃO DA TERCEIRIZAÇÃO DE SERVIÇOS NA ADMINISTRAÇÃO PÚBLICA FEDERAL: LIMITES E PERSPECTIVAS DO DECRETO N 9507/2018
}

\author{
POSSIBLE UNCONSTITUTIONALITIES IN REGULATING SERVICE OUTSOURCING IN \\ FEDERAL PUBLIC ADMINISTRATION: LIMITS AND PROSPECTS OF DECREE 9507/2018
}

\section{Raymundo Juliano Rego Feitosa}

Possui graduação em Direito pela Faculdade de Direito de Caruaru (1974), Mestrado em Sociologia pela Universidade Federal de Pernambuco (1978) e Doutorado em Direito - Universidad Autonoma de Madrid (1993).

Pós-Doutorado na Universidad Castilla La Mancha (2005). É Coordenador do Programa de Pós-Graduação em Direito (Mestrado e Doutorado) da Universidade Católica de Pernambuco (UNICAP), onde leciona na graduação e na pós-graduação. Também é professor da Universidade Estadual da Paraíba (UEPB), e da ASCES-UNITA.

E-mail: raymundo.juliano@unicap.br

\section{Roberta Cruz da Silva}

Doutoranda em Direito pela Universidade Católica de Pernambuco (UNICAP). Possui graduação em Direito e mestrado em Ciências Jurídicas, ambos pela Universidade Federal da Paraíba (UFPB). Atualmente, exerce a docência nas seguintes Instituições: Professora assistente (nível III) da Universidade Católica de Pernambuco

(UNICAP- Bacharelado em Direito e Especialização em Direito Tributário); Professora das pós-graduações da Escola Superior da Magistratura Trabalhista (ESMATRA VI); do Complexo de Ensino Renato Saraiva (CERS) e da Faculdade Egas Moniz. E-mail: roberta.cruz@unicap.br

Recebido em: 24/09/2019

Aprovado em: 24/04/2020

RESUMO: O presente artigo analisa o Decreto $\mathrm{n}^{\circ}$. 9507/2018, que passou a disciplinar a terceirização de serviços na Administração Pública Federal, tendo o seguinte problema de pesquisa como norte: o Decreto em questão extrapola os limites constitucionais estabelecidos para a contratação de execução indireta de serviços? Valendo-se do método hipotético-dedutivo, partiu da suposição de que o Decreto $n^{\circ}$. 9507/2018 afronta dispositivos da Carta Federal de 1988, inobservado a sistemática, a lógica constitucional existente para disciplinar a organização e o funcionamento da Administração Pública, bem como, a formação de seu quadro de servidores e prestadores de serviços. Após a análise do texto do Decreto, fulcrada em legislação, doutrina e jurisprudências relativas ao tema, confirmou-se sua inconstitucionalidade (hipótese inicial), ao permitir a terceirização irrestrita, e atingir a Separação dos Poderes, a legalidade, bem como, o sistema constitucional de provimento de cargos públicos e empregos. Os vícios detectados não têm impedido a sua vigência, sem que tenha havido qualquer controle pelo Poder Legislativo, Judiciário, ou Tribunal de Contas, o que, fatalmente, resultará na propositura de ações de controle de constitucionalidade, bem como, ajuizamento de mandados de segurança e outras medidas judiciais, com o intuito de garantir direitos consagrados na Constituição Federal de 1988.

Palavras-chave: Administração Pública Federal; Terceirização irrestrita; Inconstitucionalidade. 
ABSTRACT: This article aims to analyze Decree no. 9507/2018, which started to discipline the outsourcing of services in the Federal Public Administration, with the following research problem as its north: Does the Decree in question go beyond the constitutional limits established for hiring indirect services? Using the hypothetical-deductive method, it started from the assumption that Decree no. 9507/2018 affronts the provisions of the Federal Charter of 1988, not observing the systematic, the existing constitutional logic to discipline the organization and operation of public administration, as well as the formation of its staff of servers and service providers. After analyzing the text of the Decree, based on legislation, doctrine and jurisprudence related to the theme, its unconstitutionality (initial hypothesis) was confirmed, by allowing unrestricted outsourcing, and achieving the Separation of Powers, the legality, as well as the system provision of public office and employment. The defects detected have not prevented their effectiveness, without any control by the Legislative, Judicial or Court of Auditors, which, fatally, will result in the filing of constitutionality control actions, as well as filing of writ of mandamus and other judicial measures, in order to guarantee the rights enshrined in the Federal Constitution of 1988.

Keywords: Federal Public Administration; Unrestricted Outsourcing; Unconstitutionality.

SUMÁRIO: Introdução; 1 Terceirização no âmbito da Administração Pública Federal: evolução do disciplinamento legal; 2 Critérios diferenciadores da contratação indireta de serviços e da terceirização de mão de obra; 3 Aplicação do Decreto no 9507/2018 à Administração Pública Federal Direta, Autárquica e Fundacional; 4 Contornos da Terceirização nas Empresas Estatais da União; 5 Da preocupação com a Improbidade Administrativa ao zelo com as cláusulas contratuais: alguns destaques do Decreto n 9507/2018; 6 "Os espaços deixados pelo decreto à terceirização"; Conclusão; Referências.

\section{INTRODUÇÃO}

Acreditando que um trabalho científico, na área jurídica, deve aliar a pesquisa conceitual à práxis, com o intuito de evitar análises que retratam um mundo irreal e inútil (ADEODATO, 1999, p.3), este estudo trata de questões fundamentadas em sólida base teórica, mas que tem repercussão relevante de ordem prática.

O presente artigo tem por objetivo, analisar o Decreto $n^{\circ}$. 9507/2018, que passou a disciplinar a terceirização de serviços na Administração Pública Federal, tendo a seguinte pergunta de partida: o Decreto em questão extrapola os limites constitucionais estabelecidos para a contratação de execução indireta de serviços?

Esta pesquisa jurídica utilizará hipóteses testáveis como critérios orientadores. Para tanto, está fulcrada na teoria do conhecimento formulada por Popper (RODRIGUES, 2006, p.8), para quem, todo conhecimento humano é hipotético, o que implica a possibilidade de críticas, aperfeiçoamento, e de confirmação ou refutação. A "verdade" científica seria uma verdade provisória, e sua característica principal é a refutabilidade.

A produção de conhecimento científico deve ter como norte a pretensa imparcialidade do pesquisador. Leia-se: quando se faz tal afirmativa, não se objetiva indiferença axiológica ou distanciamento do objeto estudado (LACEY, pp. 471-473). Mas não há como negar que a objetividade seja a forma mais honesta e provável de garantir o sucesso - mesmo que temporário - de uma teoria, posto que, a mesma será submetida à crítica da comunidade científica (2004, pp.16-17).

A proposta de Popper (hipotético-dedutiva), decorre da premissa de que, todo o conhecimento científico consiste em conjecturas, continuamente submetidas a testes, que enquanto não forem derrubadas pela crítica, poderão ser aceitas como "verdadeiras", ou, mais precisamente, 
como melhores aproximações possíveis da verdade, reflexo da essencial falibilidade humana (2004, p.16).

Esta pesquisa, valendo-se do método hipotético-dedutivo, parte da suposição de que o Decreto $n^{\circ}$. 9507/2018 afronta dispositivos da Carta Federal de 1988, inobservado a sistemática, a lógica constitucional existente para disciplinar a organização e o funcionamento da Administração Pública, bem como, a formação de seu quadro de servidores e prestadores de serviços.

Para a solução do problema, tem-se a hipótese como resposta provisória, formulada pelo pesquisador. Alguns autores afirmam que, neste momento de criação, a neutralidade, a imparcialidade do pesquisador não teria sentido, ou mais, poderia limitar a formulação de hipóteses, coibindo uma maior ousadia. A mencionada (e questionável) imparcialidade seria bemvinda no momento do teste das hipóteses (PRADO, 2007).

O método apresentado por Popper pode ser identificado com um processo de falseamento, onde, são seguidos os seguintes passos: a partir de uma hipótese formulada (enunciado universal), deduzem-se, para testá-la, enunciados particulares acerca dos fenômenos para os quais ela foi pensada, e, se tais enunciados forem rejeitados pelas evidências empíricas, levarão, por consequência, à rejeição da própria hipótese de pesquisa. Denomina-se este método de hipotéticodedutivo, tendo em vista a centralidade, atribuída pelo próprio autor, às hipóteses (2006, pp.3334).

Para alcançar os objetivos apresentados, inicialmente, será realizada uma pesquisa exploratória, com o intuito buscar informações relativas ao estado da arte da terceirização, com a edição da Reforma Trabalhista e a análise de sua constitucionalidade pelo Supremo Tribunal Federal.

Em seguida, o estudo evolui da pesquisa exploratória para a explicativa, como intuito de analisar os pontos mais relevantes do Decreto, cotejando o seu conteúdo com a sistemática constitucional aplicável ao Poder Público, sobretudo no que concerne ao preenchimento de cargos e empregos públicos e a contratação de particulares para a execução indireta de serviços.

\section{TERCEIRIZAÇÃO NO ÂMBITO DA ADMINISTRAÇÃO PÚBLICA FEDERAL: EVOLUÇÃO DO DISCIPLINAMENTO LEGAL}

A Administração Pública brasileira, assim como a de qualquer outra nação, não é autossuficiente no atendimento às demandas da sociedade, afinal, não há ente estatal que produza todos os bens e serviços necessários para o seu pleno funcionamento. Assim, faz-se necessária a aquisição/contratação perante fornecedores diversos, promovendo, em maior ou menor escala, uma interação entre a esfera pública e a iniciativa privada, o que se torna evidente com o volume e a diversidade de atividades realizadas pelo Estado, bem como, o elevado grau de especialização que se exige em muitas delas.

Diante desse quadro irrefutável, é de fundamental relevo definir quais são os regimes jurídicos aplicáveis a esse diálogo, disciplinando-o, estabelecendo os limites legais, que devem ser norteados pelos interesses da coletividade, sem olvidar o respeito aos direitos dos contratados.

É um equilíbrio sensível, sobretudo quando a Administração Pública, após longo período adotando um perfil de gestão pautado em regras de direito público, passa a utilizar institutos usuais no direito privado. Esclareça-se, desde já, que não se está elaborando uma crítica a mecanismos, pretensamente, mais eficientes de prestação de serviços, apenas se quer ressaltar que o Estado tem um disciplinamento constitucional, que impõem limites aos institutos característicos da iniciativa privada.

Não se trata de uma contextualização banal, com respostas imediatas, livres de controvérsias: tem-se verificado, no âmbito do Poder Público, uma constante discussão entre o uso de instrumentos de gestão típicos da seara estatal, ou o alinhamento a um modelo usual no âmbito privado e, consequentemente, norteado por instrumentos normativos dessa esfera. $\mathrm{O}$ debate sobre 
o tema é, inclusive, muito bem-vindo e necessário, mas nem sempre ocorre e, em determinadas situações, textos normativos exsurgem, causando espanto aos que estudam a Administração Pública brasileira.

Exatamente nesse contexto, colocam-se os contratos de terceirização na Administração Pública, que serão objeto de análise no presente artigo.

A expressão "terceirização" corresponde ao termo inglês outsourcing, ou seja, uma fonte externa, que pode tornar a atividade econômica mais eficiente, rentável, constituindo a decisão da empresa em utilizar transações de mercado, em vez de mecanismos internos (CABRAL, 2002, p.16). Nessa linha de raciocínio, Sobrinho define terceirização como uma estratégia empresarial, nos seguintes moldes:

[...] consiste em uma empresa transferir para outra, e sob o risco desta, a atribuição, parcial ou integral, da produção de uma mercadoria ou a realização de um serviço, objetivando - isoladamente ou em conjunto - a especialização, a diminuição de custos, a descentralização da produção ou a substituição temporária de trabalhadores (2008, p. 78).

Outro esclarecimento que se mostra relevante, concerne a que tipo de atividade, usualmente, é terceirizada. Segundo Araújo (2004, p.13) costuma-se dizer que, quando o processo a ser terceirizado é anterior ao cerne da atividade dominada pela empresa, trata-se de "atividademeio", que constitui a terceirização "a montante", ou upstream. Já quando a terceirização é mais próxima do consumidor final, trata-se de "atividade-fim", com a terceirização "a jusante", ou downstream. A terceirização está, portanto, relacionada à opção organizacional entre o "fazer" e o “comprar" (CABRAL, 2002, p.16).

Em uma conjuntura de plena adoção do instituto da terceirização, tem-se mais recentemente a edição da Lei $\mathrm{n}^{\circ}$ 13.467/2017, que consubstancia a Reforma Trabalhista, alterando diversos artigos da Consolidação das Leis do Trabalho (CLT), e determinando em seu artigo $4^{\circ}$-A, que se considera prestação de serviços a terceiros, a transferência feita pela contratante da execução de quaisquer de suas atividades, inclusive a principal, à pessoa jurídica de direito privado que possua capacidade econômica compatível com a sua execução.

Segundo o texto legal em vigor, é admitida a terceirização de forma ampla. Assim, seja atividade "meio" ou "fim", permite-se a execução por terceiros, superando a distinção prevista na Súmula 331 do Tribunal Superior do Trabalho (TST), em seu item III, que relacionava a terceirização às atividades "meio" (BRASIL, TST, 2011)

Para que se avance na análise do instituto jurídico em debate, e sejam feitas futuramente, as reflexões necessárias sobre o tema, é de fundamental importância ressaltar, que o se pode terceirizar, são as atividades, e não as pessoas. Por que tal observação é tão relevante? Ao que parece, esse tem sido o cerne das questões atuais: "[...] confundir as tarefas que podem ser desempenhadas por pessoas com elas próprias - como se o ser humano, no atual estágio de avanço da sociedade, pudesse ser objeto de mercancia" (SANTOS, 2014, p.30).

Ressalte-se também, segundo os ensinamentos de Barroso, Rocha e Ribeiro, que a Reforma Trabalhista, que é o pano de fundo dessa nova regulamentação:

[...] representa um verdadeiro retrocesso social, fruto de uma estratégia políticoeconômica conservadora e 'ultraneoliberal' voltada a tornar mais incisivo o controle da força de trabalho pelo mercado ou, em outros termos, o controle da classe trabalhadora pelo capital, e que seu verdadeiro objetivo é desnaturar o direito do Trabalho para fragilizar e pressionar, individualmente, os trabalhadores [...]. (2018, p. 51). 
Tradicionalmente, quando o Poder Público se utiliza da terceirização, ocorre a contratação de uma empresa prestadora de serviços para a realização de certas atividades que, em princípio, não configuram o cerne, a tarefa principal da Administração Pública. Desse modo, a terceirização corresponde ao instituto do Direito do Trabalho transplantado para a Administração Pública (SCHIRATO, 2013, s/p).

Ocorre que, com o nóvel disciplinamento da terceirização, previsto na Reforma Trabalhista, permitindo-a irrestritamente, cabem dois questionamentos: a terceirização irrestrita é legal? Em sendo legal, pode ser utilizada no âmbito da Administração Pública?

Para a primeira pergunta, já existe resposta. O Supremo Tribunal Federal aprovou, em 30 de agosto de 2018, a terceirização irrestrita de atividades, na decisão proferida na ADPF 324/DF, de relatoria do Ministro Luís Roberto Barroso:

O Tribunal, no mérito, por maioria e nos termos do voto do Relator, julgou procedente o pedido e firmou a seguinte tese de repercussão geral:

1. É lícita a terceirização de toda e qualquer atividade, meio ou fim, não se configurando relação de emprego entre a contratante e o empregado da contratada. 2. Na terceirização, compete à contratante: i) verificar a idoneidade e a capacidade econômica da terceirizada; e ii) responder subsidiariamente pelo descumprimento das normas trabalhistas, bem como por obrigações previdenciárias, na forma do art. 31 da Lei 8.212/1993 (destaques no original). (BRASIL, STF, 2018).

Na mesma data, houve o julgamento do RE 958.252/DF, de relatoria do Ministro Luiz Fux, com o seguinte teor decisório, na tese de repercussão geral: "É licita a terceirização ou qualquer outra forma de divisão do trabalho entre pessoas jurídicas distintas, independentemente do objeto social das empresas envolvidas, mantida a responsabilidade subsidiária da empresa contratante" (BRASIL, STF, 2018).

Observe-se que, não houve menção explícita à terceirização na Administração Pública, nem mesmo no concernente às empresas estatais, e que não se pode olvidar que há um sistema constitucional que impõe respeito à uma série de exigências por parte do Poder Público e, em nenhum momento, a Corte Suprema direcionou o debate para os limites da terceirização na esfera estatal.

Faz-se necessário, enfrentado o primeiro questionamento, responder a segunda pergunta, qual seja: é legal o uso da terceirização irrestrita pelo Estado?

Pois bem, apenas três semanas após as mencionadas decisões, precisamente no dia 21 de setembro de 2018, quando os acórdãos relativos aos processos mencionados sequer haviam sido publicados, o Governo Federal editou o Decreto $n^{\circ}$ 9.507/2018, que regulamenta a execução indireta dos serviços no âmbito federal, em substituição ao Decreto ${ }^{\circ}{ }^{2}$ 2.271/1997, que disciplinou a matéria nos últimos 22 anos.

Esse estudo se debruçará, desse momento em diante, sobre possíveis inconstitucionalidades observadas no Decreto $n^{\circ} 9.507 / 2018$, seus limites e perspectivas.

Interessante notar, desde já, que o texto normativo sob análise não utiliza no texto a expressão "terceirização", mas "execução indireta dos serviços". Seria um subterfúgio?

\section{CRITÉRIOS DIFERENCIADORES DA CONTRATAÇÃO INDIRETA DE SERVIÇOS E DA TERCEIRIZAÇÃO DE MÃO DE OBRA}

O Decreto n’ 9507/2018 "Dispõe sobre a execução indireta, mediante contratação, de serviços da administração pública federal direta, autárquica e fundacional e das empresas públicas e das sociedades de economia mista controladas pela União", regulamentando tal questão a partir das previsões do Decreto-lei n ${ }^{\circ} 200 / 1967$, artigo $10, \S 7^{\text {o }}$; e da Lei ${ }^{\circ}$ 8.666/1993. 
Interessante lembrar que o Decreto-lei no 200/1967 que disciplina a organização da Administração Pública Federal, é um texto com essência de Reforma Administrativa, expressando uma "[...] preocupação com a otimização da função administrativa" (FORTINI, 2018, p. 01), consagrando o Princípio da Descentralização, com o intuito de impedir o crescimento desmedido da estrutura administrativa, ao desobrigar-se da realização material direta de tarefas executivas, sempre que seja viável.

Por sua vez, a Lei n 8666/1993, conhecida como Lei Geral de Licitações e Contratos Administrativos, trata da execução indireta de serviços, no artigo $6^{\circ}$, e considera que em atividades como demolição, manutenção, transporte, publicidade, dentre outras, a execução pode ser direta ou indireta.

Diante desse arcabouço legal, pode-se afirmar que há autorização para a terceirização? Contratação indireta de serviços é sinônimo de terceirização de mão de obra?

Para esclarecer essas dúvidas é necessária uma distinção inicial entre contratação de serviços e contratação de mão de obra.

Há um considerável equívoco quando se enxerga nos dispositivos a existência de uma autorização ampla e irrestrita para a terceirização.

Não há qualquer óbice legal para que a Administração contrate uma empresa privada para a realização material de atividades executivas, a chamada execução indireta de serviços. Inclusive, conforme o Decreto-lei $n^{\circ}$ 200/1967, esse deve ser o caminho adotado, para que se tenha uma estrutura administrativa racional.

A questão é que, quando o Poder Público contrata serviços, a Administração não deve objetivar o fornecimento de mão de obra, mas o serviço; a empresa contratada deve executar um serviço para a Administração e não contratar empregados, escolher, selecionar mão de obra para as atividades do Poder Público.

Para uma adequada compreensão da diferença, interessante se mostra o exemplo apresentado por Martins:

Suponha-se a atividade de limpeza, serviço que pode ou não ser contínuo. Suponha-se que a Administração acabara de alugar um imóvel para nele instalar uma repartição. É perfeitamente possível que contrate uma empresa de limpeza com o intuito de executar o serviço de limpeza no imóvel, serviço pontual, não prestado de modo ininterrupto e, pois, não subsumido ao inciso II do art. 57 da Lei 8.666/93. Instalada a repartição no imóvel alugado, é possível que a Administração opte por contratar uma empresa privada para realizar, dia a dia, a limpeza do local, serviço prestado ininterruptamente, sem solução de continuidade, típico serviço contínuo, subsumido ao referido inciso II do art. 57 da Lei Geral de Licitações e Contratos. Nesse caso, a limpeza é uma "necessidade pública permanente e contínua", "cujo atendimento não exaure prestação semelhante no futuro". Em ambos os casos, seja o serviço contínuo, ou não, o que quer a Administração é a execução do serviço, pouco importando qual o empregado irá realizá-lo. Ademais, inexiste qualquer tipo de relação entre a Administração e o empregado que executa o serviço. A relação é entre a Administração e a empresa contratada para executá-lo (destaques nossos). (2017, p. 4).

Na terceirização de mão de obra, simplesmente, são contratadas pessoas, trabalhadores, para executar o serviço, ou seja, delega-se a um particular a seleção de pessoal e a formação de vínculos funcionais para a realização de atribuições públicas. Schirato cita como "[...] exemplo muito atual dessa categoria de terceirização [...] o contrato firmado para fornecimento de mão de obra para verificação dos documentos de viagem de passageiros em aeroportos internacionais" (2013, s/p). 
Diante do exposto, evidenciada está a diferença: na contratação de serviços, sejam de segurança, de limpeza, de manutenção predial (comumente terceirizados), a Administração contrata uma empresa que realiza essa atividade como fim. Assim, a empresa prestará um serviço para o Poder Público. Já na terceirização de mão de obra, a empresa contratada pela Administração não realiza serviço de limpeza, nem de vigilância, tampouco de manutenção predial, mas fornece, a quem lhe contrata, empregados para realizar essas tarefas, ou seja, a atividade fim da empresa é contratar trabalhadores.

Estaria a Administração Pública contratando mão de obra, via terceirização, e denominando tal relação de contratação indireta de serviços? O Decreto $n^{\circ}$ 9507/2018, autoriza terceirização de mão de obra? Caso permita, é uma previsão caracterizada pela constitucionalidade?

Os principais aspectos do Decreto em questão serão abordados a seguir, sem o intuito de analisar artigo a artigo, inciso a inciso, mas abordando os pontos que podem conflitar com o Texto Constitucional, bem como, aqueles que têm gerado algumas indefinições quanto aos seus limites de aplicação.

\section{APLICAÇÃO DO DECRETO No 9507/2018 À ADMINISTRAÇÃO PÚBLICA FEDERAL DIRETA, AUTÁRQUICA E FUNDACIONAL}

Inicialmente, vale destacar que o Decreto promove uma alteração normativa considerável, em relação ao, até então, adotado Decreto n 2.271/1997. O último tratava apenas da Administração Direta, autárquica e fundacional, já o novo Decreto também disciplina a contratação indireta de serviços nas empresas estatais, sejam públicas ou de economia mista, conforme determina o seu artigo $1^{\circ}$, caput.

Uma aspecto do referido artigo $1^{\circ}$ causa preocupação: a inversão do tratamento dado ao tema, ou nas palavras de Fortini, “[...] o alargamento da terceirização na administração pública federal" (2018, p.2) e nas de Delgado e Amorim "[...] o Decreto 9507/2018 inverte a perspectiva deontológica até então adotada pelo Decreto 2271/1997” (2018, p. 2).

Explicando: a normativa revogada indicava as atividades passíveis de terceirização, a atual aponta um rol exíguo de atividades que não podem ser objeto de terceirização, e ainda assim, em seu artigo $3^{\circ}$, que não se aplica às empresas estatais. Assim, por exclusão, a contratação indireta de todas as demais atividades está liberada para a Administração Direta, autárquica e fundacional.

O Decreto $n^{\circ} 2271 / 1997$, no artigo $1^{\circ}, \S 1^{\circ}$, apresentava de forma explícita quais as atividades passíveis de terceirização, consideradas instrumentais, tais como: conservação, limpeza, segurança, vigilância, transportes, manutenção de prédios e equipamentos.

Por sua vez, o Decreto $n^{\circ}$ 9507/2018 não apresenta esse rol, que apesar de ser exemplificativo, é relevante, ao informar a natureza da atividade a ser terceirizada, um enquadramento necessário, para evitar usos indevidos. Assim, apenas explicita, no artigo $3^{\circ}$, quais serviços não serão objeto de execução indireta, como os que envolvam a tomada de decisão nas áreas estratégicas para o órgão ou a entidade; que estejam relacionados a poder de polícia, de regulação, de outorga de serviços públicos; exercício de poder disciplinar; e por fim, aqueles que sejam inerentes às categorias funcionais abrangidas pelo plano de cargos do órgão ou da entidade.

Ressalte-se que, de certa forma, o Decreto não inovou nessas vedações. Inclusive, já constavam na Instrução Normativa $n^{\circ}$ 05/2017, editada pelo extinto Ministério do Planejamento, Desenvolvimento e Gestão. Tais atividades não podem ser prestadas por terceiros, uma vez que envolvem o poder de decisão e planejamento de políticas públicas, além das chamadas competências típicas de Estado. Assim, algumas carreiras não serão afetadas, como por exemplo: carreiras de planejamento de políticas públicas, as que exercem Poder de Polícia, de regulação, controle, carreiras das agências reguladoras, carreiras do Banco Central, do Tribunal de Contas da União. 
Relevante, ainda, destacar o artigo $3^{\circ}, \S 2^{\circ}$, que trata da atividade de poder de polícia, ou seja, atividade de império, e constitui a única vedação absoluta à terceirização.

Excluído esse restrito rol, poderá o Ministro do Planejamento, Desenvolvimento e Gestão indicar, dentre todas as demais atividades não excepcionadas, os serviços preferencialmente sujeitos à execução indireta, conforme o artigo $2^{\circ}$ do Decreto sob estudo.

O supramencionado artigo, também desperta preocupação, pois no Decreto anterior, para que se estabelecesse que uma atividade seria alvo de terceirização, havia uma série de exigências, de justificativas, estudos que conferissem lastro a essa opção governamental, como se depreende do artigo $2^{\circ}$ do Decreto $n^{\circ}$ 2271/1997, ao exigir a justificativa da necessidade da terceirização; a relação entre demanda e contratações; uma estimativa dos possíveis resultados em termos de economicidade e de melhor aproveitamento dos recursos. São subsídios fundamentais para o uso legítimo da terceirização.

Sem essas amarras, o Ministro de Estado do Planejamento, Desenvolvimento e Gestão terá um território vasto para atuar, e pode avançar muito além das fronteiras habituais. Seria ingênuo, para não dizer pouco inteligente, imaginar que essas alterações não tem o propósito de ampliar o uso da contratação indireta nas chamadas atividades satélites, como afirma Fortini (2018, p. 3).

Um forte indício dessa tendência é o fato de que Planejamento, Desenvolvimento e Gestão, na atual gestão, perdeu seu status de ministério, com a edição da Medida Provisória $\mathrm{n}^{\circ}$ 870/2019, convertida na Lei $n^{\circ} 13.844$, de 18 de junho de 2019, e passou a integrar o Ministério da Economia, o que parece realçar a linha de raciocínio de que a gestão estará umbilicalmente relacionada à questão financeira-orcamentária. Mais que isso, que a prioridade será o custo da máquina administrativa e pretensos instrumentos de redução de gastos.

Responsabilidade com os gastos públicos é, além de um dever legal (Lei de Responsabilidade Fiscal/LC 101/2000), um anseio da sociedade brasileira, que assiste, há anos, a mostras de desperdício, privilégios e má gestão. Ocorre que, é preciso um levantamento preciso para que se estabeleça qual a escolha mais eficiente, conjugando aspectos de qualidade e custos. Essa análise, ao que parece, não tem sido realizada e a escolha pela terceirização não está embasada em dados confiáveis, sendo, praticamente, intuitiva, ou irresponsável, a critério do leitor.

Resta claro, nesse cenário, que as carreiras meramente administrativas podem sofrer uma acentuada redução nos seus quadros e que, embora se possa argumentar que são atividades meramente acessórias, devem atender a padrões de eficiência, de impessoalidade, impostos aos serviços públicos, como se abordará mais adiante.

Como afirmam Delgado e Amorim, "Trata-se de disciplina com traço liberalizante intenso [...]" (2018, p. 2), e isso se torna ainda mais evidente quando o Decreto disciplina a terceirização nas empresas estatais, como se verá adiante.

\section{CONTORNOS DA TERCEIRIZAÇÃO NAS EMPRESAS ESTATAIS DA UNIÃO}

Dando continuidade à análise da atual regulamentação da contratação indireta de serviços na esfera federal, o artigo $4^{\circ}$ do Decreto $n^{\circ} 9507 / 2018$ amplia a regulamentação e também trata da questão no tocante às empresas estatais.

A atuação empresarial da União é mais amplamente atingida pela liberalização, pois não limita sua prática, sequer, a atividades de tomada de decisão em áreas de planejamento, coordenação, supervisão e controle, ou a atividades estratégicas que envolvam o domínio de conhecimentos e de tecnologias.

Para que se deixe bem delineado o regime de terceirização, o único limite imposto às empresas estatais concerne à impossibilidade de terceirizar atividades que constituam "[...] atribuições inerentes às dos cargos integrantes de seus Planos de Cargos e Salários”, como retratado no artigo $4^{\circ}$. Ainda assim, há uma forma de optar pela terceirização: para garantir a observância 
dos princípios da eficiência, da economicidade e da razoabilidade como na ocorrência de serviço temporário; no aumento pontual do volume de serviços; na atualização de tecnologia ou especialização de serviço; e para superar impossibilidade de competir no mercado concorrencial.

Da forma como está posto no Decreto, há um amplo leque para a adoção da terceirização em atividades idênticas às atribuições dos empregados das empresas estatais.

O ponto que causa maior questionamento está na previsão que a vedação restará afastada se contrariar os princípios da eficiência, economicidade e razoabilidade, elencando como exemplo, a impossibilidade de competir no mercado. Aqui, o espírito de "flexibilização" do texto se manifesta incontestavelmente.

Estando em jogo a competitividade (e paira no ar a dúvida de como seria feita essa verificação), ainda que os serviços exijam profissionais com atribuições inerentes aos cargos integrantes do Plano de Cargos e Salários, será permitida a terceirização.

Segundo Fortini, esse é o dispositivo que merece ser analisado com atenção especial, "“[...] porque o argumento da competitividade poderá ser empregado para alavancar o esvaziamento dos empregos públicos nas estatais, em especial considerando que o decreto não aparta as atividades entre centrais ou acessórias" (2018, p. 4).

Trazendo a referida hipótese legal para o plano fático, o futuro das empresas estatais poderá ser conduzido por terceirizados, trabalhando, lado a lado, com empregados públicos, concursados, e executando atividades idênticas. E, paulatinamente, os concursos públicos serão esvaziados, o quadro de empregados efetivos das estatais, à medida que as vagas forem surgindo, poderá ser substituído por terceirizados. Ademais, a exigência contida no artigo $4^{\circ}, \S 2^{\circ}$, de que os empregados da empresa contratada atuem somente na execução dos serviços contratados, é de difícil implementação. Como realizar tal controle quando as atividades desempenhadas por concursados e terceirizados são equivalentes?

Conforme o Decreto, cabe ao Conselho de Administração da empresa estatal, ou órgão equivalente, estabelecer "[...] o conjunto de atividades que serão passíveis de execução indireta, mediante contratação de serviços" (art. $\left.4^{\circ}, \S 4^{\circ}\right)$. O referido Conselho deve ser formado de acordo com as determinações da Lei n ${ }^{\circ} 13.303 / 2016$, o Estatuto das Empresas Estatais.

Em termos práticos, a regulamentação trazida pelo Decreto permite a terceirização de atividades de qualquer natureza, acessória ou principal, ainda que sejam atribuições de empregados concursados.

É sabido que as empresas estatais têm personalidade jurídica de direito privado, e como empresas que são, devem ter uma gestão mais alinhada a modelos de gestão típicos da iniciativa privada, sobretudo as estatais que exercem atividades de natureza econômica, como por exemplo, os bancos. Ocorre que, ainda assim, há disciplinamento no artigo 37, II da Carta Federal de 1988, exigindo concurso público para o preenchimento dos empregos públicos efetivos. O Texto Constitucional foi suplantado pela Reforma Trabalhista combinada com o Decreto da terceirização?

\section{DA PREOCUPAÇÃO COM A IMPROBIDADE ADMINISTRATIVA AO ZELO COM AS CLÁUSULAS CONTRATUAIS: ALGUNS DESTAQUES DO DECRETO N 9507/2018}

Antes de enfrentar os questionamentos que foram elaborados ao longo do estudo, o que será realizado em momento oportuno, serão apresentados dispositivos que disciplinam como será a seleção e a contratação dos serviços terceirizados.

$\mathrm{O}$ artigo $5^{\circ}$ do Decreto trata dos limites à contratação, considerando a questão do nepotismo, ao proibir vínculos com pessoa jurídica na qual haja administrador ou sócio, com poder de direção, que tenham relação de parentesco com detentor de cargo em comissão ou função de confiança que atue na área responsável pela demanda ou pela contratação. Também haverá óbice 
aos vínculos contratuais quando houver parentesco com autoridade hierarquicamente superior no âmbito de cada órgão ou entidade.

Na seara pública, não obstante a existência de concursos públicos para cargos e empregos efetivos, bem como, a Súmula Vinculante $\mathrm{n}^{\mathbf{o}} 13^{1}$, institutos que primam pela moralidade, impessoalidade, e eficiência, inclusive nos vínculos estabelecidos pelo critério de confiança, ou seja, a livre nomeação para cargos e funções de confiança, o nepotismo e outras práticas ímprobas são uma das maiores fragilidades, quiçá a maior, em relação ao quadro de servidores ${ }^{2}$.

Na terceirização, ainda que existam dispositivos legais vedando práticas ímprobas, tais comportamentos serão evitados? Sem o controle das seleções por meio de concurso, não haveria uma maior facilidade para contornar as exigências legais?

Segundo Antunes, a ampliação do serviço terceirizado, ao contrário do que pregam os defensores da ideia, estimula o nepotismo e a corrupção, pois: "A medida introduz cunhas de interesses privados no interior do serviço público" (2018, s/p).

Outro questionamento, extremamente pertinente, trazido pelo referido autor: "Como uma empresa detentora de um contrato com a Administração Pública atuará para manter sua posição e eventualmente ampliá-la?" (2018, s/p).

Considerando que o Poder Público, nos últimos anos, tem passado a adotar, de forma mais ostensiva, políticas de prevenção e repressão a práticas ímprobas, como políticas de compliance, é de fundamental relevo observar como essas contratações observarão as exigências legais (FGV, 2016).

É inegável que a contratação indireta aumenta o risco da ocorrência de partidarismo, corrupção, nepotismo, dentre outras condutas ilícitas, vedadas pela Constituição Federal de 1988, pela Lei de Improbidade Administrativa (n 8429/1992) e, no caso da corrupção, além de ser ilícito civil, constitui crime, conforme o Código Penal Brasileiro.

Ainda tratando do edital de seleção das empresas terceirizadas e do contrato a ser celebrado, interessante destacar a preocupação do Decreto em estabelecer, em seus artigos $6^{\circ}$ e $7^{\circ}$, que a contratação indireta de prestação de serviços não é terceirização de mão de obra, bem como, que não há pessoalidade, nem subordinação direta dos empregados da contratada aos gestores da contratante (art. $7^{\circ}$, IV).

Outra condição é que os serviços atendam a critérios de eficiência, como é dever de todo ente estatal, podendo ser exigidos padrões de aceitabilidade e nível de desempenho para aferição da qualidade esperada na prestação dos serviços, com previsão de adequação de pagamento em decorrência do resultado.

Nesse contexto, destaca-se a ocorrência de acidentes de trabalho. Como alertam Delgado e Amorim, ao ampliar a terceirização, também se fomenta o risco de acidentes de trabalho (2018, p. 9).

Na mesma linha, Antunes cita o exemplo da Petrobras, que nos últimos 15 anos mudou o perfil dos contratados: "Hoje, os terceirizados formam dois terços de toda a mão-de-obra da petroleira. Essa expansão coincide com uma elevação dos acidentes, inclusive fatais, registrados na companhia" (2018, s/p).

Segundo dados de 2018, apresentados pela Central Única dos Trabalhadores (CUT), a terceirização aumentou o número de acidentes na Petrobras, mas as ocorrências têm sido

\footnotetext{
${ }^{1}$ Súmula Vinculante 13, STF: "A nomeação de cônjuge, companheiro ou parente em linha reta, colateral ou por afinidade, até o terceiro grau, inclusive, da autoridade nomeante ou de servidor da mesma pessoa jurídica investido em cargo de direção, chefia ou assessoramento, para o exercício de cargo em comissão ou de confiança ou, ainda, de função gratificada na administração pública direta e indireta em qualquer dos poderes da União, dos Estados, do Distrito Federal e dos Municípios, compreendido o ajuste mediante designações recíprocas, viola a Constituição Federal".

${ }^{2}$ Para um maior detalhamento, consultar os relatórios da Controladoria Geral da União (CGU) sobre o tema. Disponível em: https://www.cgu.gov.br/assuntos/atividade-disciplinar/relatorios-de-punicoes-expulsivas/arquivos/punicoesjaneiro-2019-estatutarios.pdf/view. Acesso em: 10 de fevereiro de 2019.
} 
subnotificadas para não prejudicar o Plano de Negócios da Petrobras, que precisa atingir metas de desempenho para garantir investimentos e lucro:

O Plano de Negócios da Petrobras prevê meta de 1 acidente a cada um milhão de horas trabalhadas, mas o índice de acidentes na estatal passou de 0,95 para 1,06 $10 \%$ de aumento - entre o primeiro e o segundo trimestre deste ano.

A contratação de mão de obra terceirizada é uma das principais causas de acidentes nas unidades da empresa, de acordo com levantamentos feitos pelos sindicatos de petroleiros em todo o Brasil. Segundo os dirigentes, faltam treinamento e condições adequadas de trabalho para garantir a segurança dos trabalhadores terceirizados.

De 1995 até agora, $81,48 \%$ das mortes no sistema Petrobras foram de terceirizados, contra $18,52 \%$ entre os trabalhadores contratados diretamente pela estatal, segundo os sindicatos (2018, s/p).

A letra fria da norma, portanto, precisa superar a realidade. Outro ponto que ganhou destaque no Decreto diz respeito às disposições contratuais obrigatórias.

Em alguns momentos, o texto normativo visa, claramente, proteger a Administração Pública de problemas futuros, como por exemplo, no artigo $8^{\circ}$, que exige cláusulas de declaração de responsabilidade exclusiva da contratada sobre a quitação dos encargos trabalhistas e sociais; que estabeleçam que o pagamento mensal pela contratante ocorrerá após a comprovação do pagamento das obrigações trabalhistas, previdenciárias e do FGTS; e que permitam a rescisão do contrato por ato unilateral e escrito do contratante, bem como a aplicação das penalidades cabíveis, na hipótese de não cumprimento das obrigações.

Em outros incisos do artigo $8^{\circ}$, embora o texto não se descuide da proteção dos entes estatais, também se enxerga um zelo com a figura do trabalhador terceirizado, ao exigir cláusulas que prevejam a verificação, pela contratante, do cumprimento de obrigações como pagamento de salários, adicionais, horas extras, repouso semanal remunerado; décimo terceiro salário; concessão de férias remuneradas e o respectivo adicional, dentre outras, podendo haver, diante do descumprimento, a retenção do pagamento até que a situação esteja regularizada. Ressalte-se que o sindicato representante da categoria do trabalhador deve ser notificado pela contratante, para acompanhar o pagamento das verbas mencionadas.

Destaque-se que, no tocante à responsabilidade da Administração Pública quando adota a terceirização, há regulamentação estabelecida pela Súmula 331 do TST:

[...] IV - O inadimplemento das obrigações trabalhistas, por parte do empregador, implica a responsabilidade subsidiária do tomador dos serviços quanto àquelas obrigações, desde que haja participado da relação processual e conste também do título executivo judicial.

V - Os entes integrantes da Administração Pública direta e indireta respondem subsidiariamente, nas mesmas condições do item IV, caso evidenciada a sua conduta culposa no cumprimento das obrigações da Lei n. ${ }^{\circ}$ 8.666, de 21.06.1993, especialmente na fiscalização do cumprimento das obrigações contratuais e legais da prestadora de serviço como empregadora. A aludida responsabilidade não decorre de mero inadimplemento das obrigações trabalhistas assumidas pela empresa regularmente contratada.

VI - A responsabilidade subsidiária do tomador de serviços abrange todas as verbas decorrentes da condenação referentes ao período da prestação laboral (BRASIL, TST, 2011). 
Por certo, os artigos mencionados, bem como o artigo 10 do Decreto, que estabelece as ações voltadas para gestão e fiscalização da execução dos contratos, com o intuito de acompanhar o cumprimento dos resultados estabelecidos pela contratada e verificar a regularidade das obrigações previdenciárias, fiscais e trabalhistas, tem por intuito evitar ações trabalhistas que também responsabilizem o Estado, criando uma série de mecanismos preventivos e repressivos.

\section{6 "OS ESPAÇOS DEIXADOS PELO DECRETO À TERCEIRIZAÇÃO"}

Por fim, chega-se a um ponto fundamental da análise.

O título dessa seção reproduz uma frase de Delgado e Amorim e exprime a angústia provocada pelo Decreto: o acentuado alargamento das possibilidades de uso da terceirização no Poder Público federal. Nas exatas palavras dos autores:

Voltada a atenção para os espaços deixados pelo Decreto 9.507/2018 à terceirização, preocupação central deste artigo, constata-se que, por meio dele, o Poder Executivo objetiva promover o alargamento da terceirização no âmbito da Administração Pública e das empresas estatais, em linha de compasso com as Leis $13.429 / 2017$ e 13.467/2017 que, ao promoverem a reforma trabalhista ultraflexível, autorizaram a terceirização de todas as atividades das empresas privadas O momento de sua publicação ainda revela que o Decreto 9.507/2018 busca se beneficiar do influxo interpretativo liberalizante adotado pelo Supremo Tribunal Federal na recente decisão proferida na ADPF 324/DF [...] e no RE 958.252/DF [...] (2018, p. 4).

Quando em seu artigo 14, o Decreto estabeleceu que as empresas estatais controladas pela União "[...] adotarão os mesmos parâmetros das sociedades privadas naquilo que não contrariar seu regime jurídico e o disposto neste Decreto", parecia olvidar que existe uma Constituição Federal a ser observada.

Este estudo se propõe a analisar o Decreto à luz da sistemática constitucional, e é na Carta Magna em vigor, que se encontram limites ao que está previsto na nova regulamentação. Assim, a seguir, serão apresentadas as incompatibilidades existem entre esses textos normativos.

Um primeiro obstáculo à ampliação desmedida da terceirização é o instituto do concurso público, previsto no artigo 37, II da Constituição Federal de 1988, que trata da exigência de que órgãos e entidades públicas, de todas as esferas, observem que a investidura em cargo ou emprego público depende de aprovação prévia no certame, de provas ou de provas e títulos, de acordo com a natureza e a complexidade do cargo ou emprego, exceto quando se tratar dos vínculos comissionados, que são de livre nomeação e exoneração.

As decisões do STF, relativas à terceirização, que reconheceram a legitimidade das alterações promovidas pela Reforma Trabalhista, ampliando o uso da contratação, não trataram dos limites desse instituto no âmbito das empresas estatais, considerando a exigência de concurso público para o provimento de empregos efetivos, seja nas empresas públicas, ou nas sociedades de economia mista, ainda que exploradoras de atividade econômica, tratadas no artigo $173, \S 1^{\circ}$, II da Constituição Federal em vigor.

Além do certame público, para que as empresas realizem suas atividades centrais, é permitida pela Carta Federal, em seu artigo 37, inciso XXI, a contratação de serviços, por meio de licitação, de forma excepcional, para atividades especializadas e de apoio administrativo, sob o regime da Lei $n^{\circ}$ 13.303/2016, que disciplina a licitação e contratação de bens e serviços das empresas públicas e sociedades de economia mista.

A licitação é um mecanismo legítimo, mas não tem o condão de substituir a realização de concurso, até porque, são institutos com fins diversos. A licitação tem se mostrado mais suscetível a interesses privados, à subjetividade, à manipulação de resultados. 
Ademais, quando a Carta Federal em vigor estabeleceu o concurso como rega geral para a seleção de servidores públicos, criou um sistema que conduz a esfera estatal, e que não pode ser afastado por um Decreto.

É lamentável que a Corte Suprema, quando da análise da constitucionalidade da Reforma Trabalhista, não tenha enfrentado a questão, e se manifestado acerca do conflito entre concursos e a terceirização ampliada na esfera estatal. Certamente, abriu espaço para a insegurança jurídica e futuras ações judiciais.

Se a questão já é delicada no âmbito das empresas estatais, nas entidades da Administração Pública direta, autárquica e fundacional, também há ponderações que precisam ser feitas.

Segundo o STF, a terceirização em atividades "meio" ou "fim" se fundamenta no exercício da livre iniciativa e da autonomia da vontade (BRASIL, STF, 2018). Possua vez, os entes supramencionados são de direito público, e a eles não se aplicam os fundamentos mencionados.

Quando a Lei $\mathrm{n}^{\circ}$ 8.666/1993, em seu art. $6^{\circ}$, II, estabeleceu que são serviços passíveis de contratação indireta atividades como por exemplo "[...] demolição, conserto, instalação, montagem, operação, conservação, reparação, adaptação, manutenção, transporte, locação de bens, publicidade [...]", percebe-se, claramente, que são tarefas instrumentais, acessórias.

Delgado e Amorim, apresentam a lógica contida no Texto Constitucional, em relação à divisão de competências e à execução das atividades públicas. Ressalte-se o seguinte trecho:

A Constituição concebe o Estado (Título III), conferindo-lhe uma estrutura político-administrativa de caráter federativo (art. 18) e atribuindo a cada uma de suas esferas políticas (União, Estados, Distrito Federal e Municípios) uma série de competências legislativas e materiais (arts. 21 a 24, 30 e 32), distribuídas, conforme a natureza, entre seus diversos órgãos e entidades.

Essa organização pressupõe a necessidade de estruturas permanentes e contínuas, aptas ao exercício das incumbências estatais, sejam elas políticas, tais como as atribuições dos exercentes de mandatos eletivos, dos juízes e membros do Ministério Público e dos Tribunais de Contas, ou estritamente administrativas, como as atividades de fomento, de polícia administrativa ou de serviços públicos stricto sensu, acometidas aos servidores públicos em geral e aos particulares em colaboração com o Poder Público (no caso dos serviços públicos). Daí porque, em seu Título III, que cuida da organização do Estado, a Constituição Federal traz um Capítulo (VII) especificamente destinado à estrutura e ao funcionamento da Administração Pública (art. 37) e aos deveres e prerrogativas dos seus servidores (arts. 38 a 42).

$\mathrm{O}$ art. 37, trata em vinte e dois incisos das disposições gerais sobre a Administração Pública, à exceção dos incisos XIX e XX, que disciplinam a criação de empresas estatais e suas subsidiárias.

Todos os demais vinte incisos disciplinam o regime de trabalho no âmbito da Administração Pública, dos quais dezenove enunciados cuidam de trabalho prestado diretamente pela pessoa natural (o servidor público) ao Estado, seja por vínculo permanente (cargo ou emprego público) ou transitório (cargo em comissão e contrato temporário por excepcional interesse público), mas sempre em regime de subordinação profissional deste servidor à Administração.

Somente o inciso XXI do art. 37 disciplina a contratação indireta de serviços, por meio de licitação, como modalidade excepcional de obtenção de força de trabalho, em face do caráter residual das atividades passíveis de contratação (destaques nossos) (2018, pp. 7-8).

Conforme dito anteriormente, há um sistema constitucional, uma lógica construída na Carta Magna de 1988, que exige do intérprete e do aplicador da lei uma leitura integrada desses dispositivos. 
Essa leitura que considera o todo, permite a constatação de que a Lei Maior exige um quadro de agentes públicos com perfil profissional, selecionado de forma rigorosa, conforme os princípios da impessoalidade, moralidade e eficiência. Esses profissionais são responsáveis pelas atribuições estatais, "[...] o que pressupõe a predominância das relações de trabalho firmadas diretamente entre o Poder Público e seus agentes, sujeitos ao regime estatutário ou de Direito Privado, conforme as necessidades contingentes [...]" (DELGADO; AMORIM, 2018, p. 8).

Nesse sistema constitucional, tudo o que refoge à lógica anteriormente exposta, como o instituto da terceirização, somente encontra espaço como uma solução secundária, residual em relação à contratação direta de servidores públicos, jamais como protagonista. $\mathrm{O}$ concurso público é um limite a esse protagonismo, por determinação constitucional.

É uma situação, no mínimo, sui generis, que um Decreto oriundo do Chefe do Executivo Federal afronte dispositivos constitucionais de forma tão veemente. O poder regulamentar do Chefe do Executivo federal, está previsto no artigo 84, IV, da Carta Magna de 1988, e se destina à "fiel execução" das leis.

Definitivamente, não é o que se observa no Decreto n ${ }^{\circ}$ 9507/2018, que viola, sem sombra de dúvidas, o princípio da Separação de Poderes, e da legalidade, previstos, respectivamente, nos artigos $2^{\circ}$ e $5^{\circ}$, II, da Constituição Federal de 1988.

Ainda segundo o Texto Constitucional de 1988, decretos do Presidente da República que extrapolem os limites, devem ser submetidos a controle, seja pela via judicial, seja por meio de sustação por ato do Congresso Nacional, conforme estabelece o artigo 49, V.

A própria Constituição criou mecanismos para coibir tais práticas e proteger os dispositivos legais/constitucionais de eventuais arbitrariedades oriundas de Chefes do Executivo que, em nome de interesses bem distantes do que almeja a coletividade, arvoram-se como legisladores, sem competência para tal.

\section{CONCLUSÃO}

Diante de todos os questionamentos realizados durante esse estudo, e as respostas apresentadas, o que se tem, por hora, é um cenário de profunda insegurança, que confirma a hipótese de pesquisa inicialmente aventada.

No dia 21 de janeiro de 2019 encerrou-se o prazo vacatio legis, de cento e vinte dias após a data de sua publicação, estabelecido pelo artigo 18 do Decreto $n^{\circ} 9.507 / 2018$. Até a presente data $^{3}$, não houve qualquer revisão da regulamentação. Ou seja, o texto está em pleno vigor, sem qualquer correção dos eventuais "equívocos”, sem os ajustes que parecem ser necessários para que haja uma adequação à normativa constitucional.

Diante do exposto, o caminho que parece ser mais adequado, passa pela sustação do Decreto, com o reestabelecimento dos critérios e limites adotados anteriormente, pelo Decreto $\mathrm{n}^{\circ}$ 2271/1997.

Não se pode olvidar que é necessária a observância de todo o arcabouço constitucional nas relações trabalhistas em entes públicos.

Causa espanto o silêncio, até o presente momento, do Tribunal de Contas da União sobre o referido Decreto, considerando que é de sua responsabilidade fiscalizar as contratações e admissões de pessoal realizadas pelo Estado, conforme determina o artigo 71, incisos III e IX da Constituição Federal de 1988.

Em relação ao Congresso Nacional, sobretudo, é constrangedora a inércia, considerando que, conforme explicitado anteriormente, é de sua competência sustar decretos regulamentares que extrapolam os limites constitucionais.

\footnotetext{
${ }^{3}$ Data de referência: 20 de setembro de 2019.
}

Revista de Direito Brasileira | Florianólopis, SC | v. 25 | n. 10 | p. 17-34 | Jan./Abr. 2020 
Esses mecanismos de controle externo da Administração Pública, assim como o controle realizado pela sociedade, são fundamentais para que haja respeito aos dispositivos da Carta Federal de 1988.

Percebe-se como os mecanismos de controle foram ineficientes, seja o controle interno preventivo, quando da elaboração do texto do Decreto, em que especialistas têm o conhecimento necessário, e a oportunidade, para extirpar vícios; seja o controle repressivo externo, passando pelos Poderes e entes já mencionados.

Ressalte-se, nessas últimas linhas, que esse trabalho não se opõe ao uso da terceirização, desde que, o instituto seja interpretado e aplicado conforme a Constituição em vigor, ou seja, o meio legítimo para tratar o tema, é estabelecendo a excepcionalidade da terceirização, ainda que nas empresas estatais.

Diante da inércia dos mecanismos de controle mencionados, é pertinente uma última indagação: caberá, uma vez mais, ao Poder Judiciário, precisamente ao Supremo Tribunal Federal (STF), via controle concentrado de constitucionalidade, estabelecer os limites necessários?

\section{REFERÊNCIAS}

ADEODATO, João Maurício Leitão. Bases para uma metodologia da pesquisa em direito. In: Revista CEJ. v. 3, n.7, jan/abril 1999. Disponível em:<http://www2.cjf.jus.br/ojs2/index.php/cej/search/authors/view?firstName=Jo\%C3\%A3o\%20 Maur\%C3\%ADcio\%20Leit\%C3\%A3o\&middleName=\&lastName=Adeodato\&affiliation=\&cou ntry=>. Acesso em: 20 de abr. de 2019.

AMORIM, Helder Santos. Terceirização no serviço público: uma análise à luz da nova hermenêutica constitucional. São Paulo: LTr, 2009.

ANTUNES, Ricardo. Terceirização irrestrita no setor público estimula a corrupção. Disponível em: https://www.google.com.br/amp/s/www.cartacapital.com.br/economia/terceirizacaoirrestrita-no-setor-publico-estimula-a-corrupcao/@@amp. Acesso em 30 out. 2018.

ARAÚJO, Leandro dos Reis de. Análise sobre a Atividade do "Upstream" da Indústria de Petróleo Brasileira (1997-2003). Monografia de Bacharelado. Universidade Federal do Rio de Janeiro, Instituto de Economia. Rio de Janeiro, set., 2004, p. 13.

BARROSO, Fábio Túlio; ROCHA, Cláudio Janotti da; RIBEIRO, Ailana. A “reforma trabalhista e a desnaturação do Direito do Trabalho. In: Revista Trabalhista Direito e Processo. O Direito do Trabalho: passado, presente e futuro. Ano 16, n. 58. pp. 51-65. jul-dez. de 2017. São Paulo: LTr, 2018.

BRASIL. Constituição da República Federativa do Brasil [1988]. Disponível em: http://www.planalto.gov.br/ccivil_03/constituicao/constituicao.htm. Acesso em: 08 de jan. de 2019.

BRASIL. Controladoria Geral da União. Punições Janeiro - 2019 - Estatutários. Disponível em: https://www.cgu.gov.br/assuntos/atividade-disciplinar/relatorios-de-punicoesexpulsivas/arquivos/punicoes-janeiro-2019-estatutarios.pdf/view. Acesso em: 10 de fev. de 2019.

BRASIL. Lei n ${ }^{\circ} 13.844$, de 18 de junho de 2019. Disponível em:http://www.planalto.gov.br/ccivil_03/_ato2019-2022/2019/Lei/L13844.htm. Acesso em: 27 de jun. de 2019. 
BRASIL. Lei no 13.467, de 13 de julho de 2017. Disponível em: http://www.planalto.gov.br/ccivil_03/_ato2015-2018/2017/lei/113467.htm. Acesso em: 7 de jan. de 2019.

BRASIL. Lei ${ }^{\circ}$ 8.666, de 21 de junho de 1993. Disponível em: http://www.planalto.gov.br/ccivil_03/leis/18666cons.htm. Acesso em: 08 de jan. de 2019.

BRASIL. Ministério do Planejamento, Desenvolvimento e Gestão. Instrução Normativa n ${ }^{o}$ 05/2017. Disponível em: http://www.in.gov.br/materia//asset_publisher/Kujrw0TZC2Mb/content/id/20239255/do1-2017-05-26-instrucao-normativa-n5-de-26-de-maio-de-2017-20237783. Acesso em: 10 de jan. de 2019.

BRASIL. Presidência da República. Medida Provisória no 870, de 1 de janeiro de 2019. Disponível em:http://www.planalto.gov.br/ccivil_03/_ato2019-2022/2019/Mpv/mpv870.htm. Acesso em: 10 de jan. de 2019.

BRASIL. Presidência da República. Decreto no 2271, de 7 de julho 1997. Disponível em: http://www.planalto.gov.br/ccivil_03/decreto/d2271.htm. Acesso em: : 10 de jan. de 2019.

BRASIL. Presidência da República. Decreto-lei no 200, de 25 de fevereiro de 1967. Disponível em: http://www.planalto.gov.br/ccivil_03/decreto-lei/del0200.htm. Acesso em: 10 de jan. de 2019.

BRASIL. Supremo Tribunal Federal. Súmula Vinculante 13. Disponível em:http://www.stf.jus.br/portal/jurisprudencia/menusumario.asp?sumula=1227. Acesso em: 8 de jan. de 2019.

BRASIL. Supremo Tribunal Federal. ADPF 324/DF. Relator: Ministro Luis Roberto Barroso. Requerente: Associação Brasileira do Agronegócio. 2018. Disponivel em:

http://portal.stf.jus.br/processos/detalhe.asp?incidente=4620584. Acesso em: 20 de dez. de 2018.

BRASIL. Supremo Tribunal Federal. RE 958.252/DF. Relator: Ministro Luiz Fux. Requerente: Celulose Nipo-Brasileira S.A (CENIBRA) 2018. Disponivel em:

http://portal.stf.jus.br/processos/detalhe.asp?incidente=4952236. Acesso em: 20 de dez. de 2018.

BRASIL. Tribunal Superior do Trabalho. Súmula 331. 2011. Disponível em http://www3.tst.jus.br/jurisprudencia/Sumulas_com_indice/Sumulas_Ind_301_350.html. Acesso em: 8 de jan. de 2019.

CABRAL, Sandro. Terceirização de Processos Industriais sob a Ótica da Economia dos Custos de Transação. Dissertação de Mestrado. Universidade Federal da Bahia, Escola de Administração: Salvador, 2002, p. 16.

CAMPOS (Org.): André Gambier. Terceirização do trabalho no Brasil: novas e distintas perspectivas para o debate Brasília: Ipea, 2018. Disponível em:

http://www.ipea.gov.br/portal/images/stories/PDFs/livros/livros/180215_terceirizacao_do_trabal ho_no_brasil_novas_e_distintas_perspectivas_para_o_debate.pdf. Acesso em: 27 out. 2018. 
DELGADO, Mauricio Godinho; DELGADO, Gabriela Neves. Tratado Jurisprudencial de Direito Constitucional do Trabalho. V. III. São Paulo: Revista dos Tribunais, 2013.

DELGADO, Gabriela Neves; AMORIM, Helder Santos. A ameaça da terceirização sem limites na administração pública e nas estatais. Disponível em: https://www.jota.info/opiniao-eanalise/artigos/a-ameaca-da-terceirizacao-sem-limites-na-administracao-publica-e-nas-estatais05102018. Acesso em: 27 out. 2018.

DELGADO, Gabriela Neves; AMORIM, Helder Santos. Os Limites Constitucionais da Terceirização. São Paulo: LTr, 2014.

FORTINI, Cristiana. O Decreto Federal 9.507/18 e a terceirização na administração: primeiras impressões. Disponível em: https://www.conjur.com.br/2018-set-27/interesse-publico-decretofederal-950718-terceirizacao-administracao-publica. Acesso em: 27 out. 2018.

FUNDAÇÃO GETÚLIO VARGAS. Compliance, gestão e cultura corporativa (CADERNOS FGV - Projetos). Disponível em:

https://fgvprojetos.fgv.br/sites/fgvprojetos.fgv.br/files/cadernos_compliance_site_update.pdf. Acesso em: 8 de fev. de 2019.

LACEY, Hugh. A ciência e o bem-estar humano: para uma nova maneira de estruturar a actividade científica. (Trad. de Maria Inês Rocha e Silva Lacey). In: SANTOS, Boaventura de Sousa (org.). Conhecimento Prudente para uma Vida Decente: 'Um Discurso sobre as Ciências' revisitado. 2 ed. São Paulo: Cortez, 2006.

POPPER, Karl. Lógica da Pesquisa Científica. (Trad. de Leônidas Hengenberg e Octanny Silveira da Mota). 12 ed. São Paulo: Cultrix, 2006.

POPPER, Karl. Lógica das Ciências Sociais. (Trad. de Estevão de Rezende Martins, Apio Cláudio Muniz Acquarone Filho, Vilma de Oliveira Moraes e Silva). 3 ed. Rio de Janeiro: Tempo Brasileiro, 2004.

PRADO, Daniel Nicory do. In: XVII CONGRESSO NACIONAL DO CONSELHO NACIONAL DE PESQUISA E PÓS-GRADUAÇÃO EM DIREITO. Anais eletrônicos. Belo Horizonte: CONPEDI, 2007. Disponível em: http://conpedi.org/manaus/arquivos/anais/bh/anais_na_integra.pdf. Acesso em: 13 de jan. 2019.

ROCHA, Rosely. Terceirização aumenta número de acidentes na Petrobras, denuncia Sindicato. Disponível em: https://www.cut.org.br/noticias/terceirizacao-aumenta-numero-de-acidentes-napetrobras-denuncia-sindicato-204b. Acesso em: 27 de jan. 2019.

RODRIGUES, Horácio Wanderley. Metodologia da pesquisa nos cursos de direito: uma visão crítica. In: XV CONGRESSO NACIONAL DO CONSELHO NACIONAL DE PESQUISA E PÓS-GRADUAÇÃO EM DIREITO. In: Anais eletrônicos. Fortaleza: CONPEDI, 2005. p. 08. Disponível em:<http://www.conpedi.org/manaus/arquivos/Anais/Horacio\%20Wanderlei\%20Rodrigues.pdf. Acesso em: 13 de janeiro de 2019.

SANTOS, Diogo Palau dos. Série IDP - Terceirização de serviços pela Administração Pública: estudo da responsabilidade. 2 ed. 2014. p. 30. Disponível em: [Minha Biblioteca]. 
https://integrada.minhabiblioteca.com.br/books/9788502221352/pageid/0 . Acesso em: 27 de jan. 2019.

SCHIRATO, Vitor Rhein. Terceirização na Administração Pública. In:

Fórum de Contratação e Gestão

Pública FCGP. Belo Horizonte, ano 12, n. 139, jul. 2013. Disponível em:

http://www.bidforum.com.br/bid/PDI.0006. Acesso em: 03 nov. 2018. 